\title{
Oxygen radicals generated by the enzyme xanthine oxidase lyse rat pancreatic islet cells in vitro
}

\author{
V. Burkart, T. Koike, H.-H. Brenner and H. Kolb \\ Diabetes Research Institute, University of Düsseldorf, Düsseldorf, FRG
}

\begin{abstract}
Summary. The endothelium-associated enzyme xanthine oxidase is known to generate reactive oxygen intermediates which may damage the surrounding tissue. We investigated whether reactive oxygen intermediates released by xanthine oxidase exert a toxic effect on isolated rat islet cells. The xanthine oxidase $(25 \mathrm{mU} / \mathrm{ml}) /$ hypoxanthine $(0.5 \mathrm{mmol} / \mathrm{l})$ system released reactive oxygen intermediates in vitro as detected by luminol in a chemiluminescence analysing system. The addition of nicotinamide inhibited the release of reactive oxygen intermediates in a dose-dependent manner $(50 \%$ inhibition at $20 \mathrm{mmol} / \mathrm{l}$ ). Exposure of islet cells to enzyme generated reactive oxygen intermediates caused lysis of $39 \%$ of the cells within $15 \mathrm{~h}$. Monitoring the mitochondrial function of islet cells by the conversion of tetrazolium bromide to its formazan product revealed a significant reduction of the respiratory activity down to $51 \%$ of that of the controls by
\end{abstract}

30 min after the initiation of the xanthine oxidase reaction. Mitochondrial dysfunction preceded plasma membrane damage. The addition of nicotinamide, a radical scavenger and inhibitor of the DNA repair enzyme poly(ADP-ribose) synthetase protected the islet cells from lysis and partially preserved their mitochondrial activity in the presence of reactive oxygen intermediates. We conclude that activation of the endothelial enzyme xanthine oxidase, known to be induced by mediators of immune cells or by episodes of ischaemia and reperfusion causes islet cell damage with subsequent cell death in early phases of pancreatic islet cell destruction.

Key words: Autoimmune diabetes mellitus, oxygen radicals, xanthine oxidase, islet cell lysis, nicotinamide.
In animal models of Type 1 (insulin-dependent) diabetes mellitus the first signs of islet cell destruction become evident when immune cells infiltrate the islets (insulitis). However, recent studies have revealed considerable morphological and functional changes in the microvascular system of the islets which may represent early signs of the inflammatory process. Increased permeability of islet capillary endothelial cells seem to facilitate the local extravasation of immune mediators and inflammatory cells [1]. Experimental impairment of enhanced vascular permeability suppressed the development of diabetes [2]. In islets of low-dose streptozotocin-treated mice a reduction of the capillary area was found before any sign of insulitis indicating that vasoconstriction may be involved in the initiation of islet infiltration by immune cells [3]. Moreover, in early stages of insulitis, the spontaneously diabetic $\mathrm{BB}$ rat shows considerable islet endothelial cell damage which even results in collapsed capillaries [4].

Impaired vascular permeability and disturbed capillary functions are generally associated with temporary ischaemia resulting in states of anoxia $[5,6]$. After reperfu- sion/reoxygenation of anoxic tissue the endothelial-cellassociated enzyme xanthine oxidase (XO) $[7,8]$ releases various reactive oxygen intermediates (ROI) [9] when it metabolizes the hypoxanthine which accumulates during ischaemia [10].

Besides reperfusion/reoxygenation processes, mediators of immune cells are also able to induce the endothelial-cell-associated XO. Recently it was demonstrated, that tumour necrosis factor $\alpha$ induces the conversion of xanthine dehydrogenase to $\mathrm{XO}$ in endothelial cells [11]. Interestingly, in diabetes-prone BB rats increased amounts of tumour necrosis factor $\alpha$ are released by activated macrophages [12], which play a prominent role in the process of insulitis [4, 13-15].

Pancreatic islet cells are highly susceptible to the toxic effect of ROI since they have a reduced capacity to scavenge these compounds [16]. Therefore it has been suggested that ROI are involved in the destruction of pancreatic islet cells in vivo [17-20].

The present study was designed to investigate, whether ROI, generated by the endothelial-cell-associated XO 


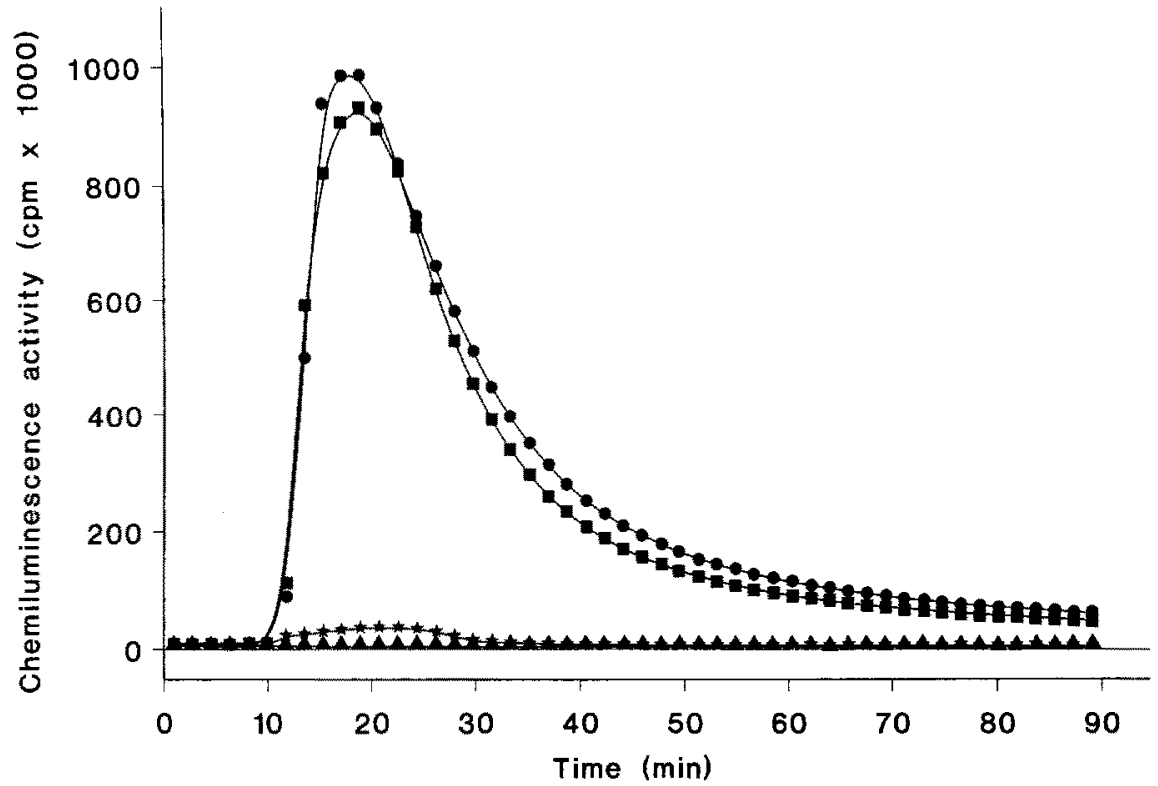

Fig. 1. Release of reactive oxygen intermediates from the xanthine oxidase $(\mathrm{XO})$ $(25 \mathrm{mU} / \mathrm{ml}) /$ hypoxanthine (HX) $(0.5 \mathrm{mmol} / \mathrm{l})$ system alone (w) or in the presence of $10^{5}$ islet cells ( ) as detected by luminol. Control samples contained islet cells with only $\mathrm{HX}(\boldsymbol{\Delta})$ or $\mathrm{XO}(\star)$. XO was added at $10 \mathrm{~min}$. Each line represents the mean of two samples (duplicates). Three experiments were performed. The curves show the results of a representative experiment

may contribute to the initial tissue damage in the process of pancreatic islet cell destruction.

\section{Materials and methods}

\section{Preparation of islet cells}

Islet cells were prepared from Wistar rats (provided from our own breeding colony by U. Kiesel) as previously described [15]. Briefly, islets were isolated by ductual injection of a collagenase solution (Serva GmbH, Heidelberg, FRG; $0.37 \mathrm{U} / \mathrm{mg}, 1.5 \mathrm{mg} / \mathrm{ml}$ in Hanks' balanced salt solution). After incubation for $45 \mathrm{~min}\left(37^{\circ} \mathrm{C}\right)$ the islets were enriched by centrifugation on a Ficoll density gradient (Ficoll 400; Pharmacia GmbH, Freiburg, FRG) and by hand-picking. The islets were then resuspended in $\mathrm{Ca}^{2+}$ - and $\mathrm{Mg}^{2+}$-free HBSS (Gibco Europe, Heidelberg, FRG) in the presence of $2 \mathrm{mg} / \mathrm{ml}$ trypsin (Boehringer Mannheim, Mannheim, FRG) and dissociated into single cells.

\section{Radioactive labelling of islet cells}

Islet cells were either left unlabelled or labelled $\left(2 \times 10^{5} \mathrm{cells} / \mathrm{ml}\right)$ by incubation with $6 \mu \mathrm{Ci} / \mathrm{ml}{ }^{3} \mathrm{H}$-leucine (specific activity $1 \mathrm{mCi} / \mathrm{ml}$, Amersham-Buchler, Braunschweig, FRG) for $20 \mathrm{~h}\left(5 \% \mathrm{CO}_{2}, 37^{\circ} \mathrm{C}\right)$ in labelling medium (leucine-free RPMI 1640 with $7.5 \mathrm{mmol} / \mathrm{glu}-$ cose and $10 \%$ fetal calf serum (FCS) (Gibco)).

\section{Xanthine oxidase/hypoxanthine}

Xanthine oxidase (XO, grade III from buttermilk, specific activity $1.2 \mathrm{U} / \mathrm{mg}$ protein) and hypoxanthine (HX, 6-hydroxypurine) were obtained from Sigma (Deisenhofen, FRG). Both reagents were dissolved freshly before use in test medium: RPMI 1640 with $7.5 \mathrm{mmol} / \mathrm{l}$ glucose supplemented with $25 \mathrm{mg} / \mathrm{l}$ ampicillin, $120 \mathrm{mg} / \mathrm{l}$ penicillin, $270 \mathrm{mg} / \mathrm{l}$ streptomycin (Serva), $1 \mathrm{mmol} / \mathrm{l}$ sodium pyruvate, $2 \mathrm{mmol} / \mathrm{l} \mathrm{L}$-glutamine, $10 \mathrm{ml} / \mathrm{l}$ non-essential amino acids $\left(100 \times\right.$, Gibco) $, 2 \mathrm{~g} / 1 \mathrm{NaHCO}_{3}, 2.38 \mathrm{~g} / 1$ HEPES (Serva) and $10 \%$ FCS. The reagents were added to the islet cells to achieve final concentrations of $25 \mathrm{mU} / \mathrm{ml} \mathrm{XO}$ and $0.5 \mathrm{mmol} / \mathrm{l} \mathrm{HX}$. Control samples received medium or $\mathrm{XO}$ or $\mathrm{HX}$ alone.

\section{Cytotoxic assay}

To determine the cytotoxic activity of ROI released by XO/HX, 5000 labelled islet cells per well $(200 \mu 1)$ of a $96-w e l l$ round bottom microtitre plate (Becton-Dickinson, Heidelberg, FRG) were incubated for $15 \mathrm{~h}\left(5 \% \mathrm{CO}_{2}, 37^{\circ} \mathrm{C}\right)$ in medium in the presence of $\mathrm{XO}$ and/or HX and nicotinamide (Sigma). The concentration of radiolabel released from the islets was then determined in $100 \mu$ lof the supernatant in a liquid scintillation counter. The total release of ${ }^{3} \mathrm{H}$-leucine was determined from the supernatant of islet cells lysed by $100 \mu l$ Triton X-100 (Serva) and the spontaneous release was determined from wells containing target cells only. In all experiments the spontaneous release of ${ }^{3} \mathrm{H}$-lencine was less than $35 \%$ of the total ${ }^{3} \mathrm{H}$-leucine release after $15 \mathrm{~h}$. The specific lysis of the target cells was calculated according to the formula:

specific lysis $(\%)=100 \times \frac{\text { (test cpm-spontaneous cpm) }}{(\text { maximum cpm-spontaneous cpm) }}$

\section{MTT assay}

The mitochondrial activity of the islet cells after exposure to $\mathrm{XO} / \mathrm{HX}$ was determined by a colorimetric assay which detects the conversion of 3-(4,5-dimethylthiazolyl-2)-2,5-diphenyltetrazolium bromide (MTT, Sigma) into the formazan product by the mitochondrial enzyme succinate-dehydrogenase [21,22]. Recently, this assay was successfully used to determine the metabolic activity of islets and insulinoma cells [23]. For the assay, $2.5 \times 10^{4}$ islet cells per well $(120 \mu 1)$ of a $1 / 2$ area microtitre plate were incubated $\left(5 \% \mathrm{CO}_{2}, 37^{\circ} \mathrm{C}\right)$ in the presence of $\mathrm{XO}$ or $\mathrm{HX}$ or both. After various time intervals the supernatants were removed, $100 \mu \mathrm{l}$ per well of an MTT solution ( $1 \mathrm{mg} / \mathrm{ml}$ in test medium) was added and the cells were incubated for another $4 \mathrm{~h}\left(5 \% \mathrm{CO}_{2}, 37^{\circ} \mathrm{C}\right)$ to allow the formation of formazan crystals. Again the supernatants were removed and the formazan crystals were dissolved in $50 \mu \mathrm{l}$ isopropanol. The optical density (OD) of the resulting blue solution was measured in an eight-channel ELISA photometer at $540 \mathrm{~nm}$ against a reference wavelength of $690 \mathrm{~nm}$. The residual mitochondrial activity of the islet cells was calculated by setting the OD of the untreated cells as $100 \%$.

\section{Chemiluminescence}

The generation of $\mathrm{ROI}$ from $\mathrm{HX}$ by $\mathrm{XO}$ was determined in a sixchannel bioluminescence analyser (Biolumat LB 9505C; Berthold, Wildbad, FRG). The ROI were detected with luminol $\left(5 \times 10^{-4}\right.$ 

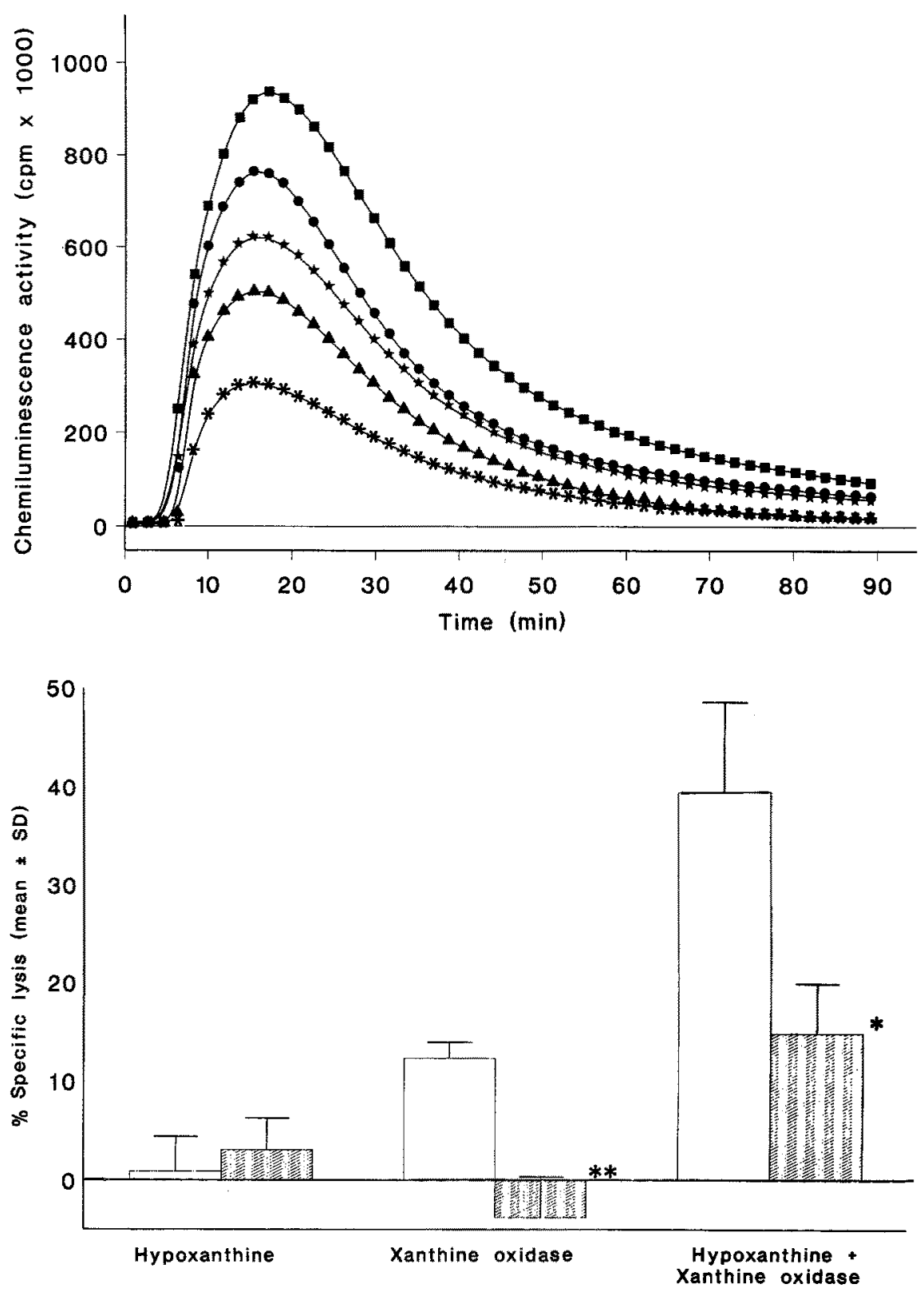

Fig. 2. Dose-dependent suppression of the luminol-detected release of reactive oxygen intermediates from the xanthine oxidase $(25 \mathrm{mU} / \mathrm{ml}) / \mathrm{hypoxanthine}(0.5 \mathrm{mmol} / \mathrm{l})$ system by nicotinamide (NA) (medium control $\mathbf{\bullet}, 5 \mathrm{mmol} / \mathrm{l} \mathrm{NA} \bullet, 10 \mathrm{mmol} / \mathrm{NA} \star$, $20 \mathrm{mmol} / 1 \mathrm{NA} \wedge, 50 \mathrm{mmol} / / \mathrm{NA} *$ ). Each line represents the mean of two samples (duplicates). Three experiments were performed. The curves show the results of a representative experiment
Fig. 3. Lysis of ${ }^{3} \mathrm{H}$-leucine labelled islet cells by hypoxanthine (HX, $0.5 \mathrm{mmol} / \mathrm{l}$ ), xanthine oxidase $(\mathrm{XO}, 25 \mathrm{mU} / \mathrm{ml})$ or a mixture of $H X$ and $X O$ in the absence ( $\square)$ or presence (囚) of $20 \mathrm{mmol} / \mathrm{l}$ nicotinamide. The specific lysis was calculated from the radioactive label released into the supernatant from 5000 islet cells after $15 \mathrm{~h}$ incubation $\left(37^{\circ} \mathrm{C}, 5 \% \mathrm{CO}_{2}\right)$. Data show mean $\pm \mathrm{SD}$ from three experiments. $* p<0.05, * * p<0.005$ compared to the lysis in the absence of nicotinamide mol/1, Sigma), which had been successfully used previously to study the kinetics of the XO catalysed oxidation of HX [24]. HX was incubated in the absence or presence of islet cells $\left(1 \times 10^{5} / \mathrm{ml}\right)$ or various concentrations of nicotinamide and the background chemiluminescence was monitored. The reaction was initiated by the addition of $\mathrm{XO}$ and the release of ROI was monitored for another $90 \mathrm{~min}$. The chemiluminescence activity from the various samples was processed by special software supplied by Berthold and plotted against time.

\section{Statistical analysis}

For statistical analysis of the data the Student's test was used.

\section{Results}

During the conversion of $\mathrm{HX}$ to uric acid, the enzyme XO releases various species of ROI. By using luminol as a detector for ROI, the kinetics of this reaction were moni- tored in a chemiluminescence analysing system (Fig. 1). The generation of ROI started immediately after the addition of $\mathrm{XO}$, reached its maximum $10 \mathrm{~min}$ later $\left(9.2 \times 10^{5} \mathrm{cpm}\right)$ and returned to almost background levels after about $60 \mathrm{~min}$. The addition of another aliquot of HX after $90 \mathrm{~min}$ induced a new start of the reaction process (data not shown). This suggests that the reaction is not terminated by the inactivation of the XO but by consumption of the substrate. Despite these observations, the actual duration of ROI formation may be underestimated, since recent observations revealed that luminol may fail to detect long-term chemiluminescence activity [25].

In the presence of islet cells the release of ROI remained almost unchanged (Fig. 1). Controls with XO or HX alone showed only a small increase of the background chemiluminescence. This indicates that neither XO activity nor a relevant substrate are present in the medium or are released by the islet cells. 


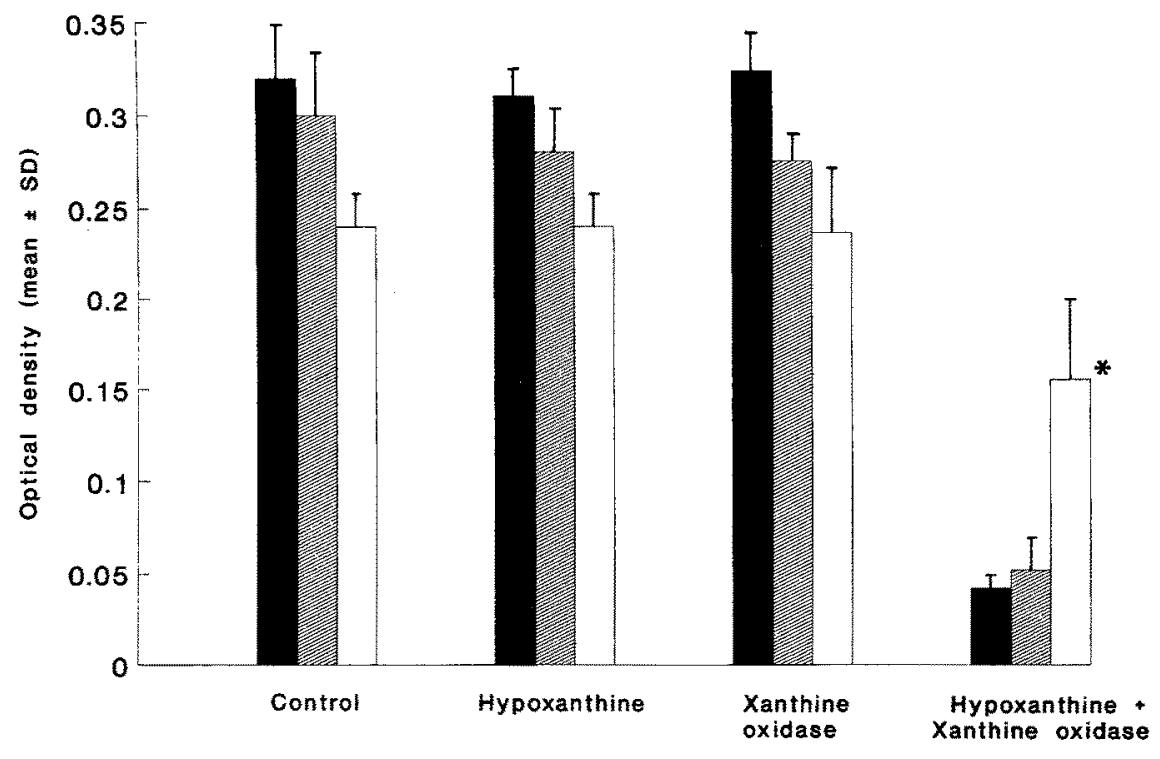

Fig. 4. Determination of the xanthine oxidase/hypoxanthine $(\mathrm{XO} / \mathrm{HX})$ mediated reduction of islet cell mitochondrial function by MTT (tetrazolium) staining. Incubation of $2.5 \times 10^{4}$ islet cells with $\mathrm{XO} / \mathrm{HX}$ was performed in the absence ( $\square$ ) or in the presence of $10 \mathrm{mmol} / \mathrm{l}$ nicotinamide (1) or $20 \mathrm{mmol} / 1$ nicotinamide $(\square)$. Data show mean \pm SD from three experiments. $* p<0.0001$ compared to the $\mathrm{HX}+\mathrm{XO}$ sample in the absence of nicotinamide

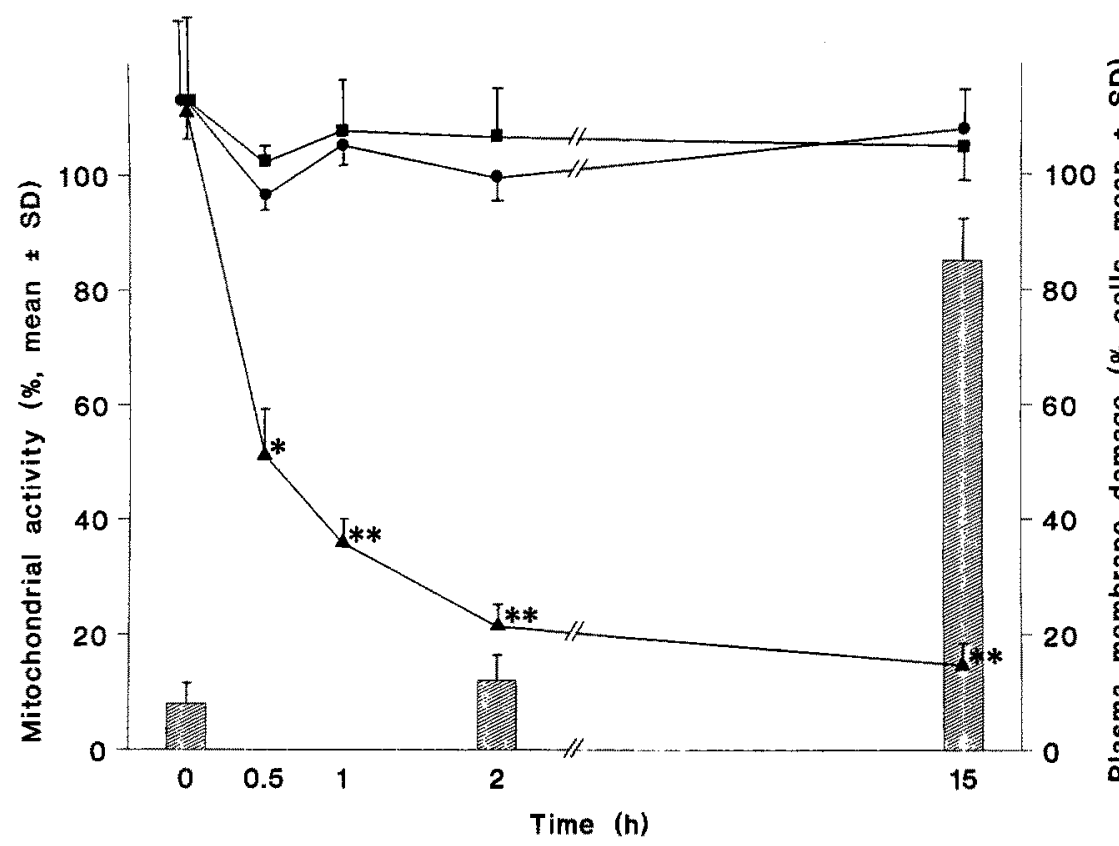

Fig. 5. Kinetics of the mitochondrial function (lines) and the plasma membrane damage (bars) of islet cells exposed to the xanthine oxidase/hypoxanthine (XO/HX) system. Incubation of $2.5 \times 10^{4}$ islet cells was performed at $37^{\circ} \mathrm{C}, 5 \% \mathrm{CO}_{2}$ for various time intervals with $\mathrm{XO}(25 \mathrm{mU} / \mathrm{ml}, \mathbf{n})$ or $\mathrm{HX}(0.5 \mathrm{mmol} / \mathrm{l}, 0)$ or with a mixture of $\mathrm{XO}$ and $\mathrm{HX}(\boldsymbol{\Lambda})$. The percentage of residual mitochondrial activity was calculated from the optical density (OD) values obtained after MTT staining. The OD values resulting from islet cells incubated with medium was set at $100 \%$. Plasma membrane damage was assessed by the trypan blue ex-

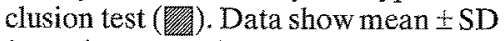
from three experiments. ${ }^{*} p<0.05$; $* * p<0.001$ compared to control, hypoxanthine and xanthine oxidase

When nicotinamide was added to the chemiluminescence assay, a clear dose-dependent decrease of free ROI levels was noted (Fig, 2). The peak chemiluminescence activity was dose-dependently reduced to $3 \times 10^{5} \mathrm{cpm}$ in the presence of increasing concentrations of nicotinamide. Half-maximal inhibition was achieved at about $20 \mathrm{mmol} / 1$ nicotinamide.

In order to investigate the cytotoxic effect of ROI against pancreatic islet cells, isolated ${ }^{3} \mathrm{H}$-leucine labelled rat islet cells were exposed to $\mathrm{XO}$ or $\mathrm{HX}$ or a combination in vitro for $15 \mathrm{~h}$. In the presence of $\mathrm{XO}(25 \mathrm{mU} / \mathrm{ml})$ and $\mathrm{HX}$ $(0.5 \mathrm{mmol} / \mathrm{l})$ islet cells were lysed to $39.0 \%$ (Fig. 3 ). When $20 \mathrm{mmol} / \mathrm{Inicotinamide}$ was added the specific lysis was inhibited to $14.8 \%(p<0.05)$. In the controls only the samples with XO alone showed more than background lysis $(12.3 \%)$, which could also be inhibited by nicotinamide.

In another experimental approach the functional activity of the islet cells was evaluated by the conversion of the tetrazolium salt MTT to its formazan product by intact mitochondria. After 15 h of incubation with the XO/HX system the islet cells showed a strongly reduced capacity to produce formazan (OD: 0.04) compared to the controls (OD: 0.29-0.31) ( $p<0.001$ ) (Fig. 4). The addition of nicotinamide at a concentration of $20 \mathrm{~mol} / 1$ resulted in a significantly increased formazan production (OD: 0.79) compared to the samples incubated with $\mathrm{XO} / \mathrm{HX}$ in the absence of nicotinamide $(p<0.0001)$.

Kinetic studies revealed a significant $(p<0.05)$ reduction of the mitochondrial function to $51 \%$ of the initial activity by $30 \mathrm{~min}$ after the initiation of the $\mathrm{XO} / \mathrm{HX}$ reaction and a further decrease to $15 \%$ after $15 \mathrm{~h}$ (Fig.5) $(p<0.001)$. Parallel studies with trypan blue as a measure of plasma membrane integrity revealed that mitochondrial dysfunction preceded plasma membrane damage (Fig. 5). In addition, up to $5 \mathrm{~h}$ after the initiation of the XO reaction no significant rise of leucine labelled products 
above the background level could be noted (data not shown).

The difference between the data obtained for cell lysis (39\%) and for plasma membrane damage (over $80 \%$ ) after $15 \mathrm{~h}$ of culture is probably caused by the different sensitivities of the two detection methods. Trypan blue seems to be more sensitive to slight functional injuries of the plasma membrane which may occur in most of the cells after $15 \mathrm{~h}$ in the presence of XO/HX. On the other hand, ${ }^{3} \mathrm{H}$ leucine- as with the ${ }^{51} \mathrm{Cr}$-label will only detect severe membrane damage resulting in leakage of intracellular constituents.

\section{Discussion}

The results of our studies demonstrate that ROI, physiologically generated by the enzyme $\mathrm{XO}$, are able to destroy pancreatic islet cells in vitro.

When XO metabolizes HX to uric acid it generates hydrogen peroxide and the superoxide radical $\mathrm{O}_{2}^{-}$which can further react to form the highly reactive hydroxyl radical $(\mathrm{OH})[6,10,26]$. Recent studies showed that mainly hydroxyl radicals are released, when pancreatic islet cells are present during this process [27]. Since hydroxyl radicals are extremely strong oxidants reacting with almost all biological substrates [28], they may be responsible for the strong reduction of glucose-stimulated insulin release from islet cells within only 90 min of XO activity [29]. Recently it was shown that scavengers of oxygen free radicals are able to protect islet cells from the deleterious effects exerted by the XO/HX system [29]. This clearly demonstrates that the toxic effects observed in the test system are mediated by ROI.

The concentration of $\mathrm{XO}$ in the culture system was in a range comparable to the enzymatic activity detected in the rat pancreas [26]. However, under in vivo conditions, scavenging of XO-generated ROI may occur, which makes it difficult to estimate the actual amount of ROI acting on the target cells.

Our results indicate that the exposure to ROI does not immediately cause the lysis of islet cells but induces some process which, during the following hours, leads to cell death. A similar delayed cytotoxic effect was observed previously when Beta cells were exposed to t-butylhydroperoxide, a potent oxidant of many cell types [30]. Our experimental system does not allow discrimination between Beta- and non-Beta cells. However, due to previous reports showing a generally increased sensitivity of islet cells to ROI [16], we assume that all cell types are affected by ROI in our assay.

Interestingly, homogenates of Beta cells exert XO activity which can be increased by streptozotocin [31]. However, control experiments of our studies showed that intact islet cells exhibit no chemiluminescence activity. This finding is confirmed by previous studies which failed to demonstrate chemiluminescence activity from islets in the absence of stimulatory agents or even in the presence of $0.5 \mathrm{mmol} / 1$ streptozotocin [32]. Therefore, we conclude that in our experiments the generation of ROI is mainly due to the activity of extracellular XO which is added to the test system.
Monitoring the mitochondrial function by the conversion of the tetrazolium salt MTT into its formazan product $[21,22]$ revealed that the respiratory activity of the islet cells is strongly depressed by $30 \mathrm{~min}$ after the initiation of the $\mathrm{XO}$ reaction, whereas significant membrane damage as detected by trypan blue exclusion and ${ }^{3} \mathrm{H}$ leucine release was not noted at this time. We therefore assume that one triggering event for ROI-mediated islet cell destruction is the impairment of mitochondrial function thereby decreasing the further energy supply. This will not cause sudden death but will gradually lead to the disintegration of the cells which is finally detectable by the release of ${ }^{3} \mathrm{H}$ leucine labelled intracellular constituents. Our assumption is supported by a recent study with rat liver mitochondria exposed to the $\mathrm{XO} / \mathrm{HX}$ system. Within only $10 \mathrm{~min}$ considerable swelling and disintegration of membranes due to lipid peroxidation was observed indicating a high susceptibility of these organelles to the toxic effects of ROI [33]. Similar observations were made by Spragg after the exposure of cultured cells to ROI [34]. In these studies, damage to intracellular constituents was found to precede functional injuries which result in the release of ${ }^{51} \mathrm{Cr}$ from pre-labelled cells. Furthermore, our results correspond to previous findings describing mitochondrial dysfunction as an early event in the process of Beta-cell damage after exposure to the diabetogenic drugs alloxan [35] and streptozotocin [36] or to the cytokines tumour necrosis factor [37] and interleukin-1 [38]. The sequence of injuries may be explained by the different effectiveness of repair systems in the two cellular components. Whereas oxidized constituents of the plasma membrane can be rapidly replaced by intact structures, the damage to complex mitochondrial enzyme systems cannot easily be repaired. Therefore, the mitochondrial injury appears to occur "before" the plasma membrane damage. These findings suggest, that ROI will damage many different constituents of the islet cell, including nuclear DNA which may also contribute to islet cell death. The pathogenetic role of mitochondrial and extra mitochondrial damage is presently under investigation.

The experimental systems allow the study of effects of substances used to protect islet cells from ROI-induced damage as may occur during early phases of islet destruction. A well-defined candidate for the protection of islet cells is nicotinamide, which is currently being used in animal studies and clinical trials aimed at the prevention of Type 1 diabetes $[39,40]$. Compared to other protective compounds, the physiological substance nicotinamide combines some unique properties [scavenging of ROI, inhibition of the nuclear DNA repair enzyme poly(ADPribose)synthetase, replenishment of the NAD pool] [41], which alone or in combination may contribute to its beneficial effects. We found that nicotinamide protected islet cells from membrane damage and preserved the respiratory function in the presence of XO. Although the exact mechanisms are still under investigation, our findings indicate that nicotinamide is able to exert its protective effect by interfering with cytotoxic processes even during the initial phase of Beta-cell damage [30].

In conclusion we have provided experimental evidence for the islet-cell damaging capacity of XO. This enzyme is 
associated with endothelial cells and may be activated in early phases of pancreatic islet destruction by mediators of immune cells or by metabolic changes occurring during episodes of hypoxia and reperfusion. Since most islet cells are in close contact with capillary endothelial cells lining the complex islet microvascular network [42] and since islet cells have a low ROI scavenger capacity [16], the activity of endothelial associated XO may substantially contribute to the initial damage of pancreatic islet cells in the pathogenesis of Type 1 diabetes.

Acknowledgements. This work was supported by the Bundesminister für Jugend, Familie, Frauen und Gesundheit and by the Minister für Wissenschaft und Forschung des Landes Nordrhein-Westfalen. T.K. was supported by Prof. K.Fujita, Founder President of the Fujita Health University of Toyoake (Aichi, Japan). We thank Mr. $R$. Verheyen for technical assistance and for help in the preparation of the manuscript.

\section{References}

1. Beppu H, Maruta K, Kürner T, Kolb H (1987) Diabetogenic action of streptozotocin: essential role of membrane permeability. Acta Endocrinol (Copenh) 114:90-96

2. Schwab E, Burkart V, Freytag G, Kiesel U, Kolb H (1986) Inhibition of immune-mediated low-dose streptozotocin diabetes by agents which reduce vascular permeability. Immunopharmacology 12: 17-21

3. Papaccio G, Chieffi-Baccari G, Mezzogiorno V, Esposito V (1990) Capillary area in early low-dose streptozotocin-treated mice. Histochemistry 95:19-21

4. Hanenberg H, Kolb-Bachofen V, Kantwerk-Funke G, Kolb H (1989) Macrophage infiltration precedes and is a prerequisite for lymphocytic insulitis in pancreatic islets of pre-diabetic $B B$ rats. Diabetologia 32: 126-134

5. Granger DN, Höllwarth ME, Parks DA (1986) Ischaemia-reperfusion injury: role of oxygen-derived free radicals. Acta Phys Scand (Suppl 548): 47-63

6. McCord JM (1985) Oxygen-derived free radicals in postischaemic tissue damage. New Engl J Med 312: 159-163

7. Jarasch E-D, Grund C, Bruder G, Heid HW, Kern TW, Franke WW (1981) Localization of xanthine oxidase in mammary-gland epithelium and capillary endothelium. Cell 25:67-82

8. Jarasch E-D, Bruder G, Heid HW (1986) Significance of xanthine oxidase in capillary endothelial cells. Acta Phys Scand (Suppl 548): 39-46

9. Zweier JI, Kuppusamy P, Lutty GA (1988) Measurement of endothelial cell free radical generation: evidence for a central mechanism of free radical injury in postischaemic tissues. Proc Natl Acad Sci USA 85: 4046-4050

10. Saugstad OD (1988) Hypoxanthine as an indicator of hypoxia: its role in health and disease through free radical production. Ped Res 23: 143-150

11. Ward PA (1991) Mechanisms of endothelial cell killing by $\mathrm{H}_{2} \mathrm{O}_{2}$ or products of activated neutrophils. Am J Med 91: 898-948

12. Rothe H, Fehsel K, Kolb H (1990) Tumor necrosis factor alpha production is upregulated in diabetes prone $\mathrm{BB}$ rats. Diabetologia 33: $573-575$

13. Kolb H, Burkart V, Appels B et al. (1990) Essential contribution of macrophages to islet cell destruction in vivo and in vitro. J Autoimmunity 3 (Suppl): 117-120

14. Lee KU, Kim MK, Amano K et al. (1988) Preferential infiltration of macrophages during early stages of insulitis in diabetesprone BB rats. Diabetes 37: 1053-1059

15. Appels B, Burkart V, Kantwerk-Funke G, Funda J, KolbBachofen V, Kolb H (1989) Spontaneous cytotoxicity of macrophages against pancreatic islet cells. J Immunol 142: 3803-3808
16. Malaisse WJ, Malaisse-Lagae F, Sener A, Pipeleers DG (1982) Determinants of the selective toxicity of alloxan to the pancreatic B cell. Proc Natl Acad Sci USA 79: 927930

17. Mendola J, Wright JR, Lacy PE (1989) Oxygen free-radical scavengers and immune destruction of murine islets in allograft rejection and multiple low-dose streptozotocin-induced insulitis. Diabetes 38:379-385

18. Heikkila RE, Cabbat FS (1978) Protection against alloxaninduced diabetes in mice by the hydroxyl radical scavenger dimethylurea. Europ J Pharmacol 52:57-60

19. Grankvist K, Marklund S, Täljedal IB (1981) Superoxide dismutase, catalase and scavengers of hydroxyl radical protect against the toxic action of alloxan on pancreatic islet cells in vitro. Biochem J 182: 17-25

20. Grankvist K, Marklund S, Täljedal IB (1981) Superoxide dismutase is a prophylactic against alloxan diabetes. Nature 294: 158160

21. Mosmann T (1983) Rapid colorimetric assay for cellular growth and survival: application to proliferation and cytotoxicity assays. J Immunol Methods 65:55-63

22. Denizot F, Lang R (1986) Rapid colorimetric assay for cell growth and survival. Modifications to the tetrazolium dye procedure giving improved sensitivity and reliability. J Immunol Methods $89: 271-277$

23. Janjic D, Wollheim CB (1992) Islet cell metabolism is reflected by the MTT (tetrazolium) colorimetric assay. Diabetologia 35 : $482-485$

24. Oyamburo GM, Prego CE, Prodanov E, Soto H (1970) Study of the enzyme-catalyzed oxidation of hypoxanthine through the chemiluminescence of luminol. Biochim Biophys Acta 205: 190-195

25. Samuni A, Krishna M, Cook J, Black CDV, Russo A (1991) On radical production by PMA-stimulated neutrophils as monitored by luminol-amplified chemoluminiscence. Free Rad Biol Med 10: 305-313

26. Parks DA, Granger DN (1986) Xanthine oxidase: biochemistry, distribution and physiology. Acta Phys Scand (Suppl 548): 87-99

27. Sakurai K, Ogiso T (1989) Studies on the biological damage by active oxygen. III. Generation of hydroxyl radical and inhibition of insulin release in hypoxanthine-xanthine oxidase system in the presence of pancreatic islet cells. Yakugaku Zasshi 109: 102-106

28. Weiss SI (1986) Oxygen, ischaemia and inflammation. Acta Phys Scand (Suppl 548): 9-37

29. Sakurai K, Ogawa Y, Miura T, Ogiso T (1988) Studies on the biological damage by active oxygen. II. Inhibition of insulin release from isolated pancreatic islets by exposure to $\mathrm{O}_{2}^{-}$-generating system of hypoxanthine-xanthine oxidase. Yakugaku Zasshi 108 : $150-155$

30. Pipeleers D, van de Winkel M (1986) Pancreatic B cells possess defense mechanisms against cell-specific toxicity. Proc Natl Acad Sci USA $83: 5267-5271$

31. Nukatsuka M, Sakurai $H$, Yoshimura $Y$, Nishida M, Kawada J (1988) Enhancement by streptozotocin of $\mathrm{O}_{2}^{-}$-radical generation by the xanthine oxydase system of pancreatic $\beta$ cells. FEBS Lett 239: 295-298

32. Asayama K, English D, Slonim AE, Burr IM (1984) Chemiluminescence as an index of drug-induced free radical production in pancreatic islets. Diabetes 33:160-163

33. Mehrotra S, Kakkar P, Viswanathan PN (1991) Mitochondrial damage by active oxygen species in vitro. Free Rad Biol Med 10: $277-285$

34. Spragg RG (1991) DNA strand break formation following exposure of bovine pulmonary artery and aortic endothelial cells to reactive oxygen products. Am J Respir Cell Mol Biol 4: 4-10

35. Boquist L, Ericsson I (1984) Inhibition by alloxan of mitochondrial aconitase and other enzymes associated with the citric acid cycle. FEBS Lett 178:245-248

36. Eizirik DL, Sandler S, Sener A, Malaisse WJ (1988) Defective catabolism of D-glucose and L-glutamine in mouse pancreatic islets maintained in culture after streptozotocin exposure. Endocrinology 2: 1001-1007 
37. Eizirik DL (1988) Interleukin-1 induced impairment in pancreatic islet oxidative metabolism of glucose is potentiated by tumor necrosis factor. Acta Endocrinologica (Copenh) 119: $321-325$

38. Sandler S, Bendtzen K, Borg LAH, Eizirik DL, Strandell E, Welsh N (1989) Studies on the mechanism causing inhibition of insulin secretion in rat pancreatic islets exposed to human interleukin-1 $\beta$ indicate a perturbation in the mitochondrial function. Endocrinology 124; 1492-1501

39. Yamada K, Nonaka K, Hanafusa T, Miyazaki A, Toyoshima $H$, Tarui S (1982) Preventive and therapeutic effects of large-dose nicotinamide injections on diabetes associated with insulitis. An observation in nonobese diabetic (NOD) mice. Diabetes 31: $749-753$

40. Herskowitz RD, Jackson RA, Soeldner JS, Eisenbarth GS (1989) Pilot trial to prevent type I diabetes: progression to overt IDDM despite oral nicotinamide. J Autoimmunity 2:733-737
41. Uchigata Y, Yamamoto H, Kawamura A, Okamoto H (1982) Protection by superoxide dismutase, catalase and poly(ADP-ribose)synthetase inhibitors against alloxan- and streptozotocininduced islet DNA strand breaks and against the inhibition of proinsulin biosynthesis. J Biol Chem 257: 6084-6088

42. Bonner-Weir S, Orci L (1982) New perspectives on the microvasculature of the islets of Langerhans in the rat. Diabetes 31:883889

Received: 17 February 1992

and in revised form: 14 July 1992

Dr. V.Burkart

Diabetes Research Institute

Auf'm Hennekamp 65

W-4000 Dússeldorf

FRG 